\title{
Analysis of the Technical and Sanitary Constraints of the Traditional Breeding of Guinea Fowl in "Région des Savanes" of Northern Togo
}

\author{
Yao Lombo ${ }^{1,2}$, Kokou Tona ${ }^{2}$ and Bèdibètè Bonfoh ${ }^{1}$ \\ 1. Centre de Recherche Agronomique de la Savane Sèche (CRASS), Institut Togolais de Recherche Agronomique (ITRA), Lomé BP \\ 1163, Togo \\ 2. Laboratoire des Sciences et Techniques de Production Avicoles, Centre d'Excellence Regionale des Sciences Aviaires (CERSA), \\ Ecole Supérieure d’Agronomie (ESA), Université de Lomé, Lomé BP 1515, Togo.
}

\begin{abstract}
A survey to determine the causes of mortality of guinea fowl and the technical and sanitary constraints of the traditional breeding of guinea fowl was carried out among 106 poultry farmers from the Savannah Region in North Togo. The survey also made it possible to identify the breeding constraints and the endogenous practices of rearing of the guinea fowl. The results obtained from the investigations are: (i) the high rate (69.81\%) of illiterates is not conducive to the definition or control of plans for prophylaxis and rationing. (ii) Breeders are unaware of disease-resistant strains of guinea fowl. (iii) Guinea fowl breeding starts with traditional methods, with $33.96 \%$ of the breeders who leave the guinea fowl in the wilderness and $13.21 \%$ who breed them in conflagration pell-mell. (iv) The formulations of food rations in order to satisfy the nutritional requirements of guinea fowl are virtually non-existent. The sources of proteins sometimes supplemented are only termites. However, food imbalance leads to growth lags. (v) Prophylaxis plans are not followed by breeders. Fifty two percent (52\%) of the breeders self-medicate and other breeders (9.43\%) do not treat. Several plants are used alone or in combination to control poultry diseases. (vi) biosecurity measures are non-existent in the farms (48.11\% of the farmers give the dead guinea fowl to the children for consumption and $66 \%$ of the breeders throw the dead guinea fowl in the wild). (vii) The major constraints identified in this investigation are the remoteness of the veterinary supply centers, the lack of access to quality veterinary services, the low rate of training of farmers, the inadequate support of pastoralists livestock equipment; (viii) the problem of predators (93.40\%) and the problem of access to effective veterinary products (79.25\%) were noted.
\end{abstract}

Key words: Guinea fowl farming, constraints, “Région des Savanes”, Togo.

\section{Introduction}

Guinea fowl farming is widespread in Togo, especially in the two northern regions where it is an essential pivot in the incomes of peasant households [1-3]. Guinea fowl has a higher market value than chicken. Despite low productivity [4-6], high exposure to diseases [7-10] and the difficult environment in which the breeding of the guinea fowl evolves, the guinea fowl plays a major socio-economic role, occupying an important part in poultry farming in northern Togo. Given the enthusiasm of breeders to

Corresponding author: Yao Lombo, Master in developmental biology, research fields: option nutrition and reproduction. tackle this breeding despite the difficulties they face, it seems wise to think of ways to improve this poultry farming [11].

Since July 2014, the non-governmental organization named AVSF (Agronomes et Vétérinaires Sans Frontières) has started the implementation of the project "Sustainability and resilience of family farming in 'Région des Savanes' of Togo". In addition to the promotion of sustainable agricultural practices and the development of agroforestry, this project aims to reduce the economic vulnerability of farms by increasing their income through market gardening and small-scale livestock farming so that agricultural households are more resilient to external shocks, price 
variability, etc. In order to achieve this objective, it has been necessary to improve guinea fowl breeding because this farming is still very unproductive due to high mortality of guinea fowl [12]. Contrary to what is observed in traditional chicken breeding, raising the guinea fowl is difficult. For more than two decades, research activities undertaken here or elsewhere have been trying to find solutions to improve this species. However, the observation made on the ground is that nothing has changed. It is within this framework that upon request, ITRA signed the two-year service contract (2015 and 2016) with AVSF to conduct the study. The aim of the study was to identify the shortcomings of current practices in health and zootechnical monitoring that may jeopardize the success of guinea fowl farming. Specifically, they are: (1) Investigate the causes of high mortality of guinea fowl and the constraints of rearing in the project area; (2) Identify effective endogenous hatchery farming practices;

\section{Materials and Methods}

Primary data on the breeding of the guinea fowl, its feeding and zootechnical and sanitary constraints were collected through a bibliographic review. This phase of bibliographic data collection was followed by a field survey in which 106 farmers of guinea fowl were interviewed on their practices of raising guinea fowl. The survey was conducted in "Région des Savanes" of northern Togo (Fig. 1). The surveyed breeders are divided into six cantons, namely the cantons of Sanfatoute, Kourientré and Naki-ouest for the prefecture of Tône and Biankouri, Timbou and Nadjoundi for the prefecture of Cinkassé. In the course of this survey, a questionnaire was administered to each breeder to collect information that could be used to identify the causes of high mortality of traditional breeding stock. The endogenous practices of raising of guinea fowl were also recorded using this questionnaire.

The collected data were entered and processed using

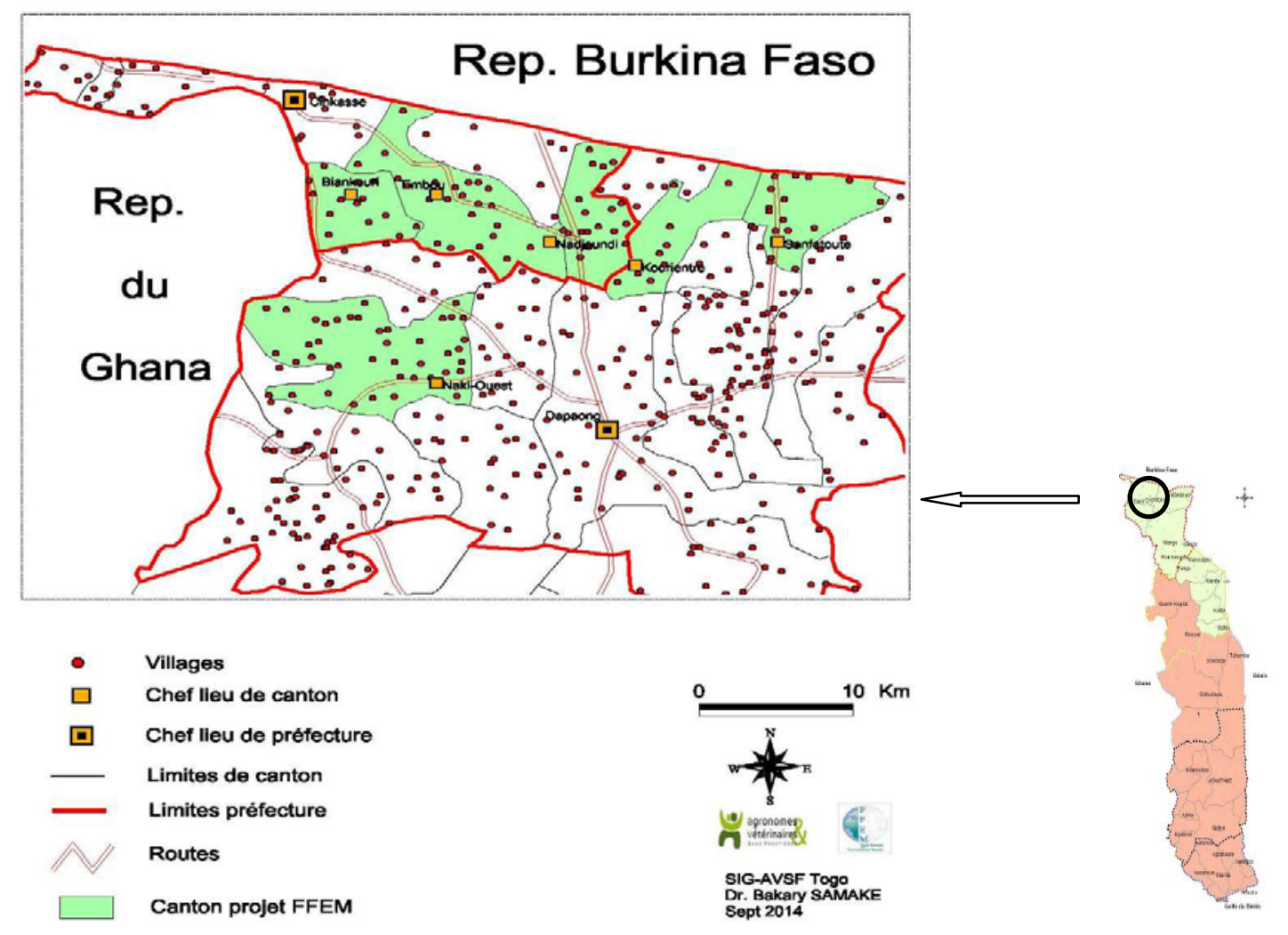

Fig. 1 Project intervention area. 
the EpiData, Version 3.1 and Excel software, Version 2007. This allowed making tables and graphs and calculate percentages.

\section{Results and Discussion}

The results of this investigation revealed a number of facts that could justify the high mortality rates often recorded in family farms.

\subsection{Interest in Raising Guinea Fowl in Rural Areas}

Surveys conducted between 2015 and 2017 in the Savannah Region of Togo have shown that the average backyard is composed of 36 hens, 16 guinea fowl, 6 pigeons and 1 duck.

Guinea fowl is mainly grown for: marketing (51\%); ownership (38\%); sacrifices and donations (11\%).

The income of poultry households is mainly guinea fowl (77\%) followed by chicken (23\%); Ducks are raised more for consumption (82\%) followed by chicken (14\%) and guinea fowl (4\%). As a sacrificial use, guinea fowl is second (11\%) after the chicken (65\%).

Income derived from the farming of household guinea fowl is mainly used for health, schooling, clothing and the purchase of chemical fertilizers.

In the area of investigation, the selling price of guinea fowl depends on three factors: the time of year, the need for the farmer and the locality where the farmer lives. Generally, guinea fowl is sold cheaper in remote areas where access is difficult and more expensive in the city. In addition, it is expensive during the holiday season (Christmas party, New Year, Ramadan, Tabaski) during which demand is high. The study also revealed that during the month of May the guinea fowl is also expensive because at the moment, the breeders keep the breeders to have eggs and start a new campaign. Likewise, during this meal, guinea fowl benefits from the greenery following the arrival of the first rains and becomes heavier. The cheapest guinea fowl is sold at a minimum price of 1,500 F CFA and maximum of 2,700 F CFA whereas the most expensive guinea fowl is sold at minimum price 2,000 F CFA and maximum of 3,000 F CFA. In general, the price of guinea fowl is increasing since in 2008 Guinea fowl cost an average of 1,800 FCFA in Dapaong [13].

\subsection{Characteristics of the Surveyed Breeders}

The breeding of guinea fowl is an activity practiced exclusively by men. Women rarely intervene in this activity. These men are mostly (95.28\%) of the agro-pastoralists. The level of illiteracy is higher in traditional poultry farming. Indeed, $69.81 \%$ of the breeders surveyed are illiterate, $18.87 \%$ have the primary level, $8.49 \%$ have done the college and only 2.83\% have done the high school. The same observation was made in Benin, Burkina Faso, Niger, the Democratic Republic of Congo and Zimbabwe [14-20].

The high rate of illiterate breeders does not facilitate the control and implementation of plans for prophylaxis and food rations. Training programs should therefore take account of this parameter, which could be one of the causes of mortality of guinea fowl.

\subsection{Methods of Rearing Guinea Fowl}

\subsubsection{High Guinea Fowl Strains}

In terms of disease hardiness, good hatching, good size and good production, black-legged, purple camel-topped feather guinea fowl ranks first (22\%) in the preferential classification of guinea-fowl strains high. The same reasoning was narrowed by the breeders (3\%) who hold the gray feathered guinea fowl with white breast and primary feathers. On the other hand, the white guinea fowls, more susceptible to diseases, are depreciated by the breeders. The few breeders (2\%) who hold them evoke the reasons for the beauty of the feather and want to preserve this strain. For guinea fowl with black feather, the main reason mentioned by the holders (3\%) is that they are highly sought after during ceremonies.

For a good breeding of guinea fowl, the guinea fowl with gray feather with purple camel and black legs is 
recommended due to its good size, hardiness to diseases, good production and hatching of eggs. On the other hand, the white-feathered guinea-pig strain is more susceptible to diseases.

\subsubsection{Mode of Operation of Guinea Fowl}

The start-up is poorly practiced among the breeders with $33.96 \%$ of the breeders who make the start in rambling and $13.21 \%$ who do it in conflagration pell-mell. Of course, $50 \%$ of breeders breed guinea fowl in segregated confinement, but the forms of confinement described by them are far from resolving their expectations in terms of reducing mortality rates. Indeed, it should be noted that in the study environment, there are three forms of breeding in confinement:

(1) Retain the mother chicken under a picket preventing it from wandering with the guinea fowl;

(2) Take the guinea fowl and chicken each morning to the field where they are raised up to nearly two months of age.

(3) Keep the guinea fowl and chicken in a hut or under a basket braid and feed them with termites and corn or crushed millet.

It was noted by breeders that field-bred guinea fowls were less prone to diseases than those raised in house confinement.

In confinement, the breeders are content to lock up guinea fowl and chicken. The use of litter and the heating of the hen house or booths are not yet the subject of special attention.

In reality, the start-up phase is an 8-week period [21-24]. This is the critical phase in the success of raising hens. At this age, the very fragile guinea fowl must be protected against abiotic factors (cold and predators) and biotic factors (pathologies).

The recommended form of confinement is to keep the guinea fowl and chicken in a hen house or in a well-ventilated starting cage containing litter and to warm the enclosure if necessary (especially during the rainy season).

Habitat. Sixty-five percent (65\%) of the interviewees constructed improved traditional poultry houses (PTAs) compared with 35\% who use the old habitat model. However, thirty-four percent (34\%) of the breeders who built the PTAs did not disinfect them at all. In addition, the observation on the ground is that the PTA is built for all poultry species of the breeder $[17,25]$. In rural areas, there is no specific habitat for guinea fowl. The housing conditions of these poultry do not differ to those observed in Burkina Faso [23, 26-28.] and Benin [16, 28]. Under these conditions, animal performance will decrease both in disease resistance and in production [29].

Power supply. Fig. 2 shows the different foods distributed to guinea fowl and the percentage of people who use them: termites (84\%), corn (78\%), millet (69\%), rice $(44 \%)$, and soybeans (41\%), fishmeal (28\%), sorghum (17\%), millet grains (10\%), eggshells (8\%) and sorghum grains (4\%). Fifty-five percent (55.66\%) of the breeders mix ingredients before distributing them to guinea fowl. However, the food formulations used are only a mixture of cereals: crushed corn-sorghum-millet-rice or corn-sorghum-millet. Sources of protein are absent in the diet. The proteins are only supplemented sometimes as termites especially for guinea fowl. The frequency of distribution of the food generally varies according to the age of the guinea fowl. Three times per day (89.62\% of the cases) in guinea fowl, it is reduced to twice daily (64.15\% of cases) in adults. Other breeders (26.42\%) distribute some seeds in the morning and the animals complete their rations outside. According to breeders, those who distribute three times or more a day (7.55\%) aim at gaining the confidence of their livestock by seeking to create a habit through reconciliation [19, 25, 28]. Water distributed to guinea fowl comes from boreholes and wells (99.05\%), ponds and rivers $(0.95 \%)$. This result shows that the source of water-related poultry infestation would not reside in the origin of distributed water, but rather in its management or maintenance of watering troughs. Indeed, water is served mostly in drinkers made of pierced pots or in pieces of pot. The sources of infestation 


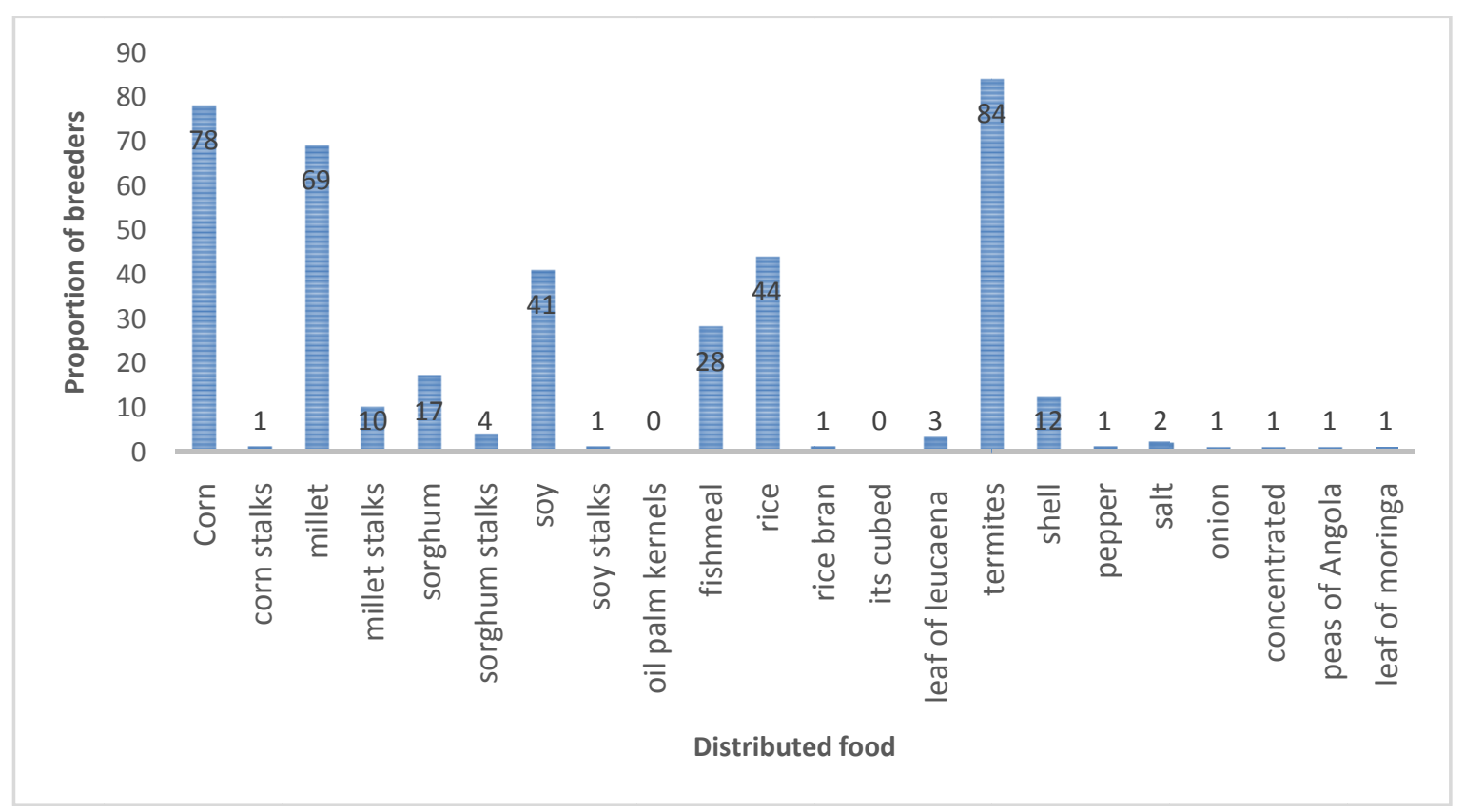

Fig. 2 Feed used in the feeding of guinea fowl by breeders.

Table 1 Health measures and intervention frequencies in the year (\% of the number of people applying them).

\begin{tabular}{llll}
\hline \multirow{2}{*}{ Frequency of intervention } & \multicolumn{3}{c}{ Health measures } \\
\cline { 2 - 4 } & Vaccination & Internal deworming & External deworming \\
\hline once per year & $12.26 \%$ & $0.94 \%$ & $9.43 \%$ \\
Twice a year & $62.26 \%$ & $23.58 \%$ & $15.09 \%$ \\
3 times a year & $1.89 \%$ & $55.66 \%$ & $8.49 \%$ \\
Not at all & $23.58 \%$ & $19.82 \%$ & $62.26 \%$ \\
\hline
\end{tabular}

of water-related guinea fowl were mentioned by Bessin et al. [25]. During the rainy season, the guinea fowl drinks in pools and puddles, available around the houses. In the dry season, it drinks from the debris of calabashes or broken canaries, rarely cleaned and made available to all animals in the barnyard. Adequate watering, adapted to the size of the farm, with minimal hygiene will reduce the frequency of nephritis and visceral drops [25].

Health of guinea fowl. In terms of health and medical follow-up, no prophylactic plan is followed by the farmers. Fifty-two percent (52\%) of the breeders self-medicate, compared with $44 \%$ who use a livestock auxiliary (AVE) in the event of disease in the livestock. Certainly, some farmers are vaccinating or de-paving poultry (Table 1), but operations are not systematically applied. And $25.47 \%$ of the people surveyed do both the vaccination and the internal and external deworming but these operations are not repeated on the same animals to guarantee them health protection throughout the year. These are sporadic actions often applied to a band of poultry. Moreover, other breeders (9.43\%) do not make any treatment (Fig. 3). The survey revealed that $23.58 \%$ of breeders do not vaccinate guinea fowl, 19.82\% do not do internal deworming and $62.26 \%$ do not do external deworming.

The health monitoring as described by the breeders does not make it possible to have an interesting rate of success in family breeding [30]. Self-medication can lead to deaths due either to the incorrect use of products or to the use of products not adapted to the rearing of guinea fowl. The neglect of the maintenance and disinfection operations of the poultry houses leads to the spread of germs, which is the cause of several diseases which may lead to the death of several individuals. 


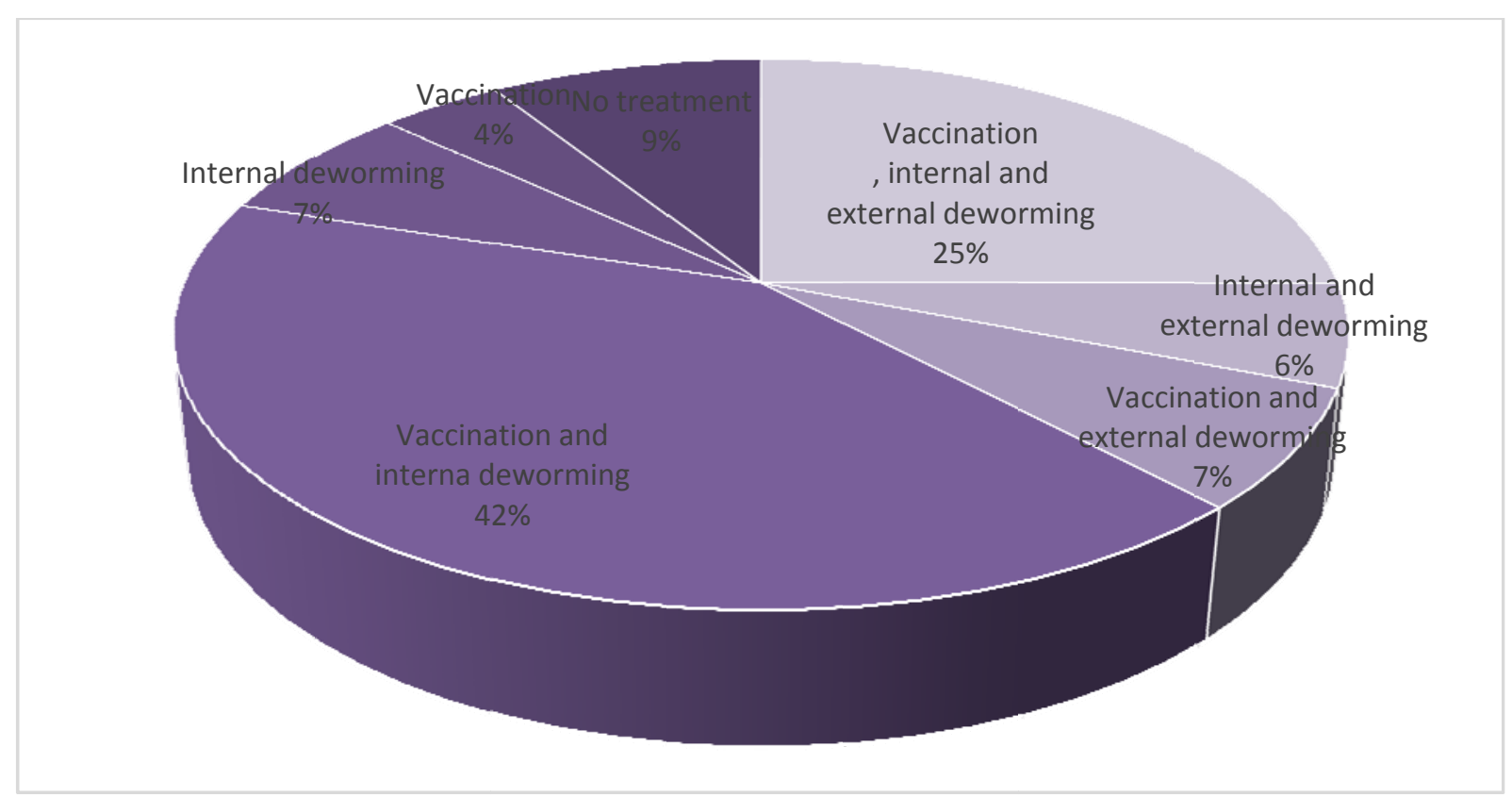

Fig. 3 Sanitary measures applied in traditional breeding (\% of number of people).

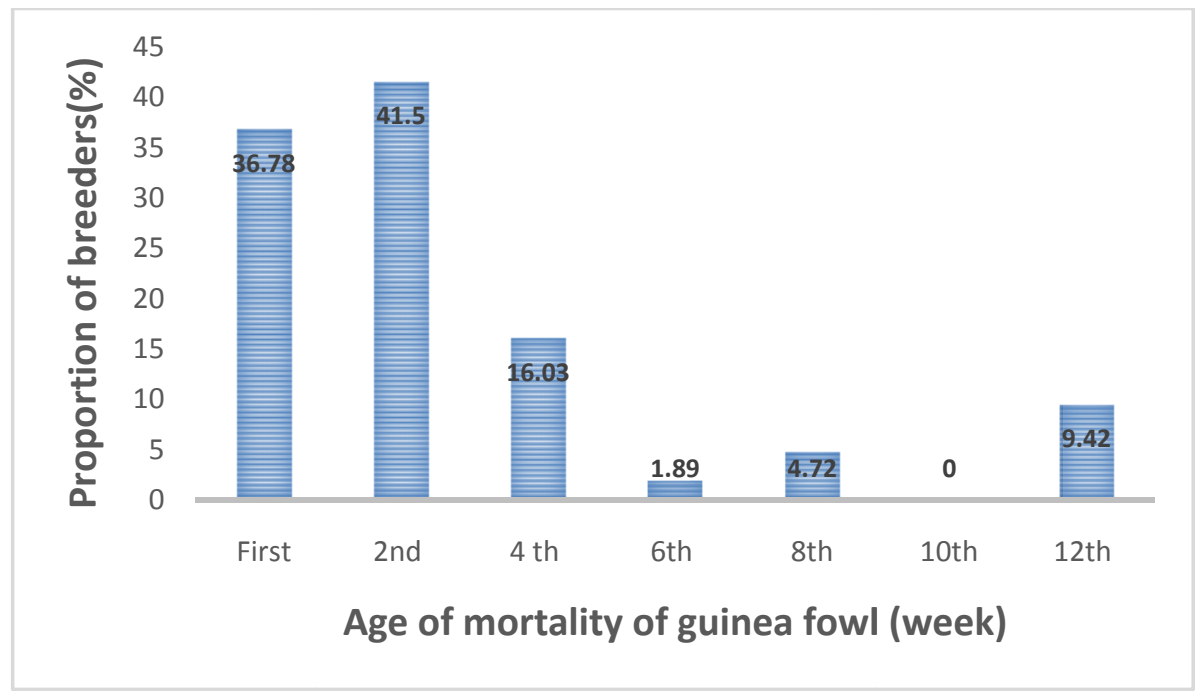

Fig. 4 Importance of guinea fowl mortality by age according to the breeders.

The dead guinea fowls are either thrown into the wild ( $66 \%$ of the breeders) or given to the children to eat ( $48.1 \%$ of the breeders). These practices pose risks of contamination of the rest of the farmyard by germs [31].

According to the breeders, the mortality of the guinea fowls are greater between the first and the second week (Fig. 4) with recrudescence at 3 months of age (9.42\% of the breeders). These mortalities occur between July, August and September (Fig. 5). These results confirm those obtained in Burkina Faso [25, 32], Nigeria [4] and Benin [16]. According to these authors, the maximum mortality period is in August during the rainy season. The high moisture levels that characterize the rainy season and the way in which farms do not take into account the physiological characteristics of guinea fowl favor the onset and persistence of diseases on farms. The guinea fowl is a bird that regulates its internal temperature worse until it is completely feathered. The ambient temperature in which the guinea 


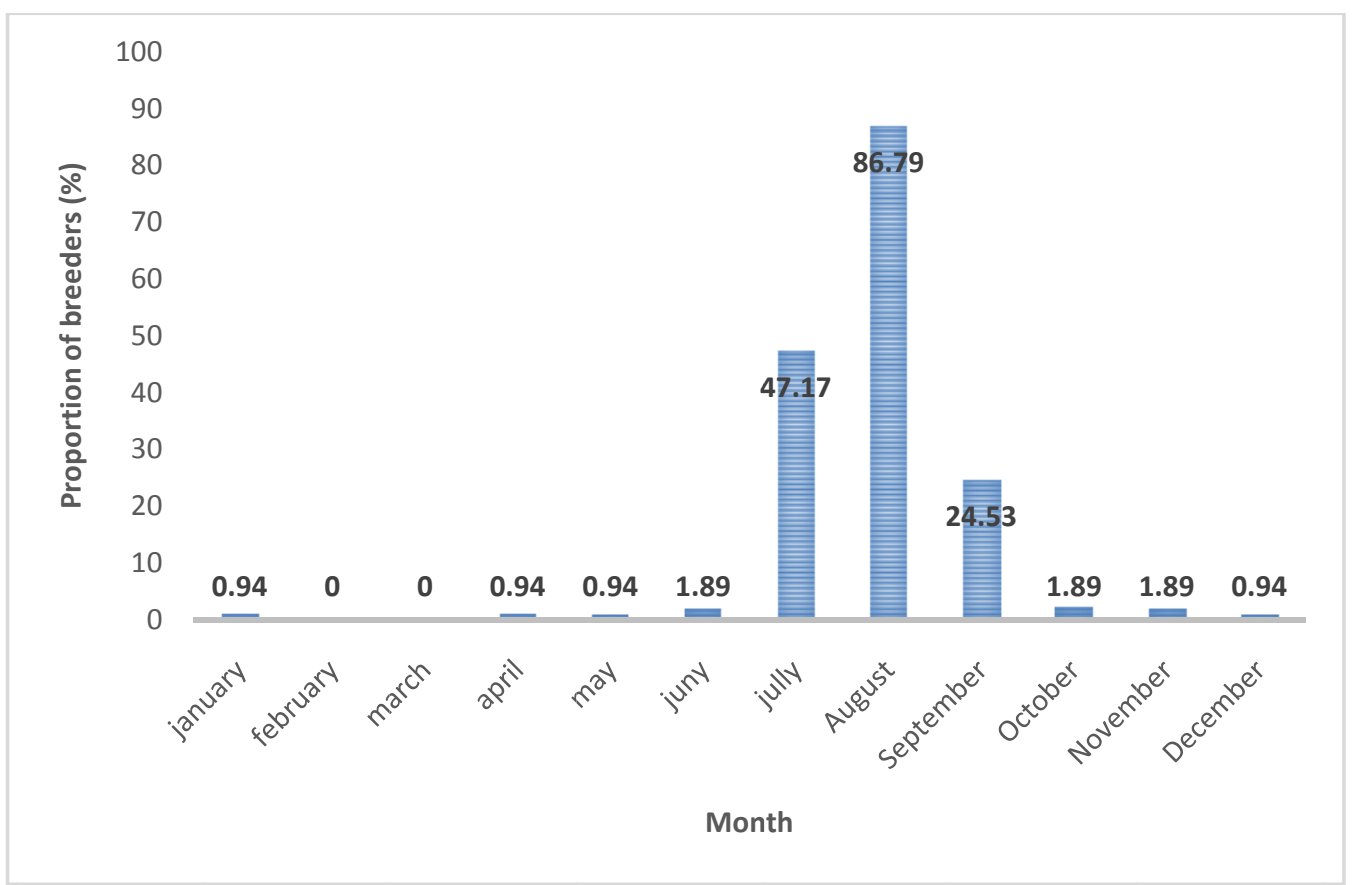

Fig. 5 Importance of guinea fowl mortality according to the month of the year according to the breeders.

fowl lives must never be less than $25{ }^{\circ} \mathrm{C}$. The temperature should be around 36 to $38^{\circ} \mathrm{C}$ under a breeder and $28^{\circ}$ in the environment [22]. It is therefore necessary to provide for heating of the habitat during the cold period and when the chicken house is very wet.

\subsection{Local Know-How in the Control of Guinea Fowl Diseases}

In terms of health monitoring, the permanent non-availability of veterinary products is the subject of alternative endogenous solutions. Traditional know-how identified includes the use of bark, leaves or roots of plants and prepared recipes. These plants are used alone or in combination to control poultry diseases (Table 2). The most frequently used plants are Vitellaria paradoxa (39\%), Khaya senegalensis (34\%), Parkia biglobosa (24\%), Anogéissus leocarpus (15\%), Euphorbia poisonii (9\%), Nicotiana tabacum (7\%). The forms of use of these plants and the diseases targeted are summarized in Table 3 . According to the users, all these recipes have a positive effect if they are used preventively. However, used in case of clinical signs as most breeders (88\%), the result is always mediocre.

3.5 Constraints to the Development of the Breeding of the Guinea Fowl

Several constraints hamper the optimum profitability of raising guinea fowl in Togo such as the management and technical support services.

3.5.1 Constraints Related to Management and Technical Support Services

The constraints noted by the breeders are: remoteness of veterinary supply centers, lack of access to quality veterinary services, low rate of livestock training (30.19\%), inadequate breeders' support.

The problem of predators (93.40\%), the problem of access to efficient veterinary products (79.25\%) and the problem of lack of access to financial credits for livestock (56, 60\%) (Table 4).

3.5.2 Technical Constraints Related to the Raising of Guinea Fowl in Rural Areas

The technical constraints of raising guinea fowl in "Région des Savanes" are: the high rate of illiterate breeders (70\%) who do not facilitate the control and the implementation of the plans of prophylaxy and food 
Table 2 Plants used in traditional pharmacopoeia in the control of guinea fowl diseases in northern Togo.

\begin{tabular}{|c|c|c|c|c|}
\hline Name in French & Scientifique name & Name in local language(Moba) & Percentage of people using it & Part of the plant used \\
\hline Karité & Vitellaria paradoxa & Sang & $39 \%$ & bark \\
\hline Caïlcédrat & Khaya senegalensis & Gbek & $34 \%$ & bark \\
\hline Néré & Parkia biglobosa & Doug & $24 \%$ & bark, root \\
\hline Bouleau d'Afrique & Anogéissus leiocarpus & Nassiek & $15 \%$ & bark and Leaf \\
\hline- & Euphorbia poissonii & Péne & $9 \%$ & Chopped stem \\
\hline Tabac & Nicotiana tabacum & Table & $7 \%$ & stem and bark \\
\hline- & Pteleopsis suberosa & Gbrek & $6 \%$ & bark \\
\hline Anacardier & Anacardia occidentalis & - & $5 \%$ & bark \\
\hline Kade & Acacia albida & kokon Goundipiéli & $5 \%$ & bark \\
\hline Neem & Azadirachta indica), & Titong & $4 \%$ & Leaf and root \\
\hline Figuier & Ficus exasperata & Kankansio & $3 \%$ & bark \\
\hline Manguier & Mangifera indica & Batousang & $2 \%$ & bark \\
\hline Gingembre & Zingiber officinale & Kakadoro & $1 \%$ & root \\
\hline Tamarinier & Tamarindus indica & Poug & $1 \%$ & fruit \\
\hline- & - & Wobdibina & $1 \%$ & root \\
\hline- & - & Kok & $1 \%$ & root \\
\hline- & Lannea microcarpa & Chinchbk & $1 \%$ & root \\
\hline- & Pterocarpus erinaceus & Naton & $1 \%$ & root \\
\hline- & - & Djoundjoun & $1 \%$ & root \\
\hline- & - & Poumpoum & $1 \%$ & Leaf \\
\hline Citronnier & Citrus sp. & Ankandjoli & $1 \%$ & $\begin{array}{l}\text { Lemon juice in drinking } \\
\text { water }\end{array}$ \\
\hline- & - & Bongnoal & $1 \%$ & bark \\
\hline- & Sterculia setigera & Nafonfohlou & $1 \%$ & Plant \\
\hline Aloma & Vernonia amigdalina & Sowaka & $1 \%$ & Leaf \\
\hline - & & Djegore & $1 \%$ & bark* \\
\hline- & & gbengbelgue & $1 \%$ & root \\
\hline
\end{tabular}

* This tree would be toxic if used in high doses.

rations. Formulations of food rations are almost non-existent and no plan of prophylaxis is followed by the breeders. The poverty of food rations gleaned by birds, coupled with rough farming conditions, leads to poor zootechnical performance; Breeders do not recognize rustic guinea fowl strains.

The start-up is poorly practiced among the breeders with $33.96 \%$ of the breeders who make the start in rambling and $13.21 \%$ who do it in conflagration pell-mell. Such an environment poses the problem of failure to respect zootechnical and hygienic standards and, above all, extrinsic and intrinsic requirements specific to each species, which probably leads to a drop in numerical productivity.

Fifty-two percent (52\%) of the farmers are self-medicated and other farmers (9.43\%) do not receive any treatment.

Biosecurity measures are non-existent in the farms (48.11\% of the farmers give the dead guinea fowl to the children for consumption and $66 \%$ throw away the dead guinea fowl in the nature) $[6,26]$.

\subsection{Axis of Development}

The suggestions formulated by the farmers and considered as priorities for the optimization and development guinea fowl breeding are: Organization and training of breeders on breeding techniques; Technical support for breeders.

3.6.1 Need for Training through the Participatory Approach

Training programs for village livestock auxiliaries and herders as well as vaccination and deworming 
Table 3 Endogenous know-how used in the control of guinea fowl diseases.

\begin{tabular}{|c|c|c|}
\hline “Disease” & Recipe & Route of administration \\
\hline Lice and ticks & Sterculia setigera + potash & apply on the body \\
\hline \multirow[t]{2}{*}{ Lice in the henhouse } & $\begin{array}{l}\text { Anogéissus leiocarpus } \\
\text { Nicotiana tabacum }\end{array}$ & $\begin{array}{l}\text { Leave the leaves in the chicken coop; the lice are attracted by } \\
\text { the smell and rise on the leaves. Once on the leaves one can } \\
\text { then burn them to the fire }\end{array}$ \\
\hline & $\begin{array}{l}\text { Barks of Parkia biglobosa or Mangifera indica } \\
\text { or Vitellaria paradoxa+ bongnoal* or Khaya } \\
\text { senegalensis, or Ficus exasperata }\end{array}$ & $\begin{array}{l}\text { Spread the tobacco powder in the chicken coop } \\
\text { A plant can be used alone or in combination with others, all } \\
\text { soaked in simple water. To this certain solution you add } \\
\text { either traditional potash or some tetracycline capsules. } \\
\text { Renew preparations every day }\end{array}$ \\
\hline \multirow[t]{2}{*}{$\begin{array}{l}\text { White diarrhea, } \\
\text { presence of worms in } \\
\text { droppings, drooping } \\
\text { wings }\end{array}$} & $\begin{array}{l}\text { Azadirachta indica, or Anacardia occidentalis } \\
\text { or kok* or Lannea microcarpa or leaves of } \\
\text { Nicotiana tabacum or Tamarindus indica fruit or } \\
\text { root of Wobdibina* or root of Acacia albida or }\end{array}$ & $\begin{array}{l}\text { From the } 5 \text { th day of the hatch give } 2 \mathrm{~g} / \mathrm{l} \text { in the drinking water } \\
\text { for } 3 \text { days. It is allowed to pass for } 7 \text { days and then the } \\
\text { treatment is continued for } 3 \text { days and so on for up to three } \\
\text { months. }\end{array}$ \\
\hline & $\begin{array}{l}\text { slices of Euphobia poisonii or leaf of } \\
\text { Djoundjoun* or leaf of Poumpoum* } \\
\text { Miracle Powder of the Great Seminary } \\
\text { Tetracycline Lemon Solution }\end{array}$ & $\begin{array}{l}\text { To } 10 \mathrm{ml} \text { of the lemon juice are added } 10 \text { capsules of } \\
\text { tetracycline from the pharmacy; the whole is then dissolved } \\
\text { in a liter of water. This solution serves as drinking water for } \\
\text { guinea fowl for } 7 \text { consecutive days. A week is allowed and } \\
\text { the treatment is resumed for one week and so on for up to } 3 \\
\text { months. }\end{array}$ \\
\hline Smallpox & Bark of Pteleopsis suberosa & In drinking water \\
\hline \multirow{2}{*}{$\begin{array}{l}\text { Taming the guinea } \\
\text { fowl }\end{array}$} & Sorghum germinated + Mustard & $\begin{array}{l}\text { Mix the sprouted sorghum and the mustard and give to the } \\
\text { guinea fowl }\end{array}$ \\
\hline & Sour in the water & $\begin{array}{l}\text { Dip the sours in the water and give this water to the guinea } \\
\text { fowl }\end{array}$ \\
\hline $\begin{array}{l}\text { Hunting the hawks } \\
\text { from the barnyard }\end{array}$ & Fruit of dioscorea & $\begin{array}{l}\text { Attach the fruit of Dioscorea to the tip of a mast and implant } \\
\text { this mast in the yard of the guinea fowl or chicks }\end{array}$ \\
\hline
\end{tabular}

* Name of the plant in Moba (local language).

Table 4 Importance of the constraints/difficulties related to the development of the farming of guinea fowl in "Région des Savanes".

\begin{tabular}{ll}
\hline Constraints/Difficulties & Proportion of breeders (\%) \\
\hline Problems of predators (hawks and ravens) & 93.40 \\
Problem of access to effective veterinary products & 79.25 \\
Financial problems (difficulty accessing credits) & 56.60 \\
Problems of farmers and herders (poisoning of guinea fowl) & 16.98 \\
Problem of space to develop the activity & 5.66 \\
Problem of envy (theft of guinea fowl) & 16.98 \\
\hline
\end{tabular}

campaigns for poultry started with the agricultural sector support project should continue. The results showed a high rate of illiteracy (69.81\%). This situation must be taken into account the formulation of the programs of training/sensitization of the breeders on the various themes [33]. For example, formulating and delivering these courses in local languages, preferring role plays rather than translating complicated scientific concepts into local languages. It is important that training be carried out in a participatory manner. Participation and learning are enriched when participants contribute to the discussion. It is therefore essential that participants are encouraged to give their own experiences. In this way the discussions take their point of view regarding local practices and the problems encountered by breeders. Practical instructions, where participants prepare equipment in local materials, mix local foods, etc., will then significantly increase their ability to remember what they have learned. The participatory method and 
self-learning will create a direct connection between training and the challenges that breeders encounter when they apply the new methods.

The reasons of organization of the breeders in associations will put forward the solidarity between breeders. These associations could serve as a channel for sensitization or training and intermediate to negotiate credits for members.

\subsubsection{Need for Material Support}

The accompanying measures sought by breeders relate to easy access to livestock equipment and products and the establishment of a credit granting system adapted to the livestock sector. There is also a need to increase the supply of veterinary products by bringing them closer to the village level. The local veterinary services set up [6] through the AVEs must be supported and strengthened. Similarly, the current system for monitoring the quality of veterinary products placed on the market must be more dynamic and rigorous.

Predator problems $(93.40 \%)$ and poisoning of guinea fowl during the growing season $(16.98 \%)$ are constraints for family rearing. Against predators, support should be given for the construction of improved traditional poultry houses promoted by the PAEF (Projet d'Amélioration de l'Elevage Familial), ASATO (Appui à la Sécurité Alimentaire au Togo) [6] and most recently Agricultural Sector Support Project.

Again problem of space to develop the activity and problem of envy (theft of guinea fowl) support should be given to farmers to build fences around chicken coops. This will prevent the birds from wandering.

\section{Conclusions}

This survey revealed that guinea fowl breeding in rural areas has always remained traditional. The major constraints of guinea fowl farming in the Savanes region of Togo are:

(1) The remoteness of the supply centers for veterinary products, the lack of access to quality veterinary services, the low rate of training for livestock farmers, the lack of support for livestock breeders;

(2) The high rate of illiterate breeders that does not facilitate control and enforcement of prophylaxis and dietary plans;

(3) The problem of predators and access to credit for livestock farming;

(4) The absence of associations of guinea fowl breeders.

The permanent unavailability of veterinary products leads breeders to seek alternative endogenous solutions through the use of bark, leaves or roots of plants to fight against poultry diseases. It is therefore important to verify the effectiveness of these endogenous or local practices for improving the breeding of guinea fowl in rural areas.

\section{References}

[1] Aklobessi, K., and de Souza. 2007. Etude de la compétitivité de la filière avicole togolaise. ANPAT/AVSF.

[2] Anpat. 2009. "Présentation la filière avicole du Togo." Journees Techniques Avicoles de L’Uofa/Uemoa.

[3] Dsid. 1996. Recensement national de l'Agriculture. Togo p. 303.

[4] Ayorinde, K. L. 1990. "Problems and Prospects of Guinea Fowl Production in the Rural Areas of Nigeria.” In Proceedings of an International Workshop on Rural Poultry Development in Africa (Sonaiya, E.B., Ed.), Ile Ife, Nigeria, 106-115.

[5] Bonfoh, B., Ankers, P., Pfister, K., Pangui, L. J., and Toguebaye B. S. 2000. "Répertoire de quelques contraintes de l'aviculture villageoise en Gambie et proposition de solution pour amelioration.” In Issues in Family Poultry Research and Development, edited by EB Sonaiya. Proceedings of International Workshop held Dec. 9-13, 1997 at Mbour, Sénégal, p. 204.

[6] Moula, N., Detiffe, N., Farnir, F., Antoine-Moussiaux, N., and Leroy, P. 2012. "Aviculture familiale au Bas-Congo, République Démocratique du Congo (RDC).” Livestock Research for Rural Development 24 (5): 1-15.

[7] Bett, H. K., Bett, R. C., Peters, K. J., Kahi, A. K., and Bokelmann, W. 2012. "Linking Utilization and Conservation of Indigenous Chicken Genetic Resources to Value Chains.” Journal of Animal Science Advances 2 (1): 33-51.

[8] Sonaiya, E. B., and Swan, S. E. 2004. Production en 

of Guinea Fowl in "Région des Savanes" of Northern Togo

Aviculture familiale, Organisation des Nations Unies pour l'Alimentation et l'Agriculture (FAO) Rome, p.140.

[9] Sourou, S. Y. 2002. Enjeux de la production de pintades en Afrique Occidentale : conception et adoption d'un schéma de prophylaxie pour une production améliorée au Togo. Rapport d'activité. Dapaong, Togo, p. 13.

[10] Yindo. 1997. Ethnologie de la pintade: Cas de la région Centrale, Mémoire ESA-UB 83 pages.

[11] Badje, Y. B. 2008. Revue du secteur avicole. Division de la Production et de la SantÉ Animales de la FAO Togo, p. 39

[12] Lombo, Y., Dao, B. B., and Ekoue, K. S. 2011. "Élaboration d'un itinéraire technique d'élevage de pintadeaux adapte en élevage familial au Togo.” Neuvième Journées de la Recherche Avicole, Tours, 29 et 30 mars 2011.

[13] FAO. 2008. Etudes des filières avicoles et des chaînes de commercialisation des volailles et des produits avicoles au Togo, p. 88.

[14] Batcha, N. 2000. Profil pathologique des pintadeaux en élevage traditionnel dans la Région des Savanes au Togo. Mémoire. Ecole Supérieure d'Agronomie. Université de Lomé, p. 68.

[15] Bonkoungou, G. F. X. 2005. "Characteristics and Performance of Guinea Fowl Production under Improved and Scavenging Conditions in the Sahelian Region of Burkina Faso.” M.Sc. Thesis, the Royal Veterinary and Agricultural University, Copenhagen, Denmark, p. 68.

[16] Dahouda, M., Toleba, S. S., Youssao, A. K. I., Bani Kogui, S., Yacoubou Aboubakari, S., and Hornick, J.-L. 2007. "Guinea Fowl Rearing Constraints and Flock Composition under Traditional Management in Borgou Department, BeninFamily Poultry, 17 (1) \& (2).

[17] Gnassimgbe, C. N. 1983. Contribution à l'étude de l'élevage de la pintade au Togo. Thèse: Méd. vét: Dakar, 19.

[18] Moussa Amadou B., I. D. I. A., and Benabdeljelili, K. 2011. "Characterization of Traditional Poultry Farming in Niger.” World’s Poultry Science Journal 67 (3): 517- 30.

[19] Sanfo, R., Boly, H., Sawadogo, L., and Ogle, B. 2007. "Caractéristiques de l'élevage villageois de la pintade locale (Numida meleagris) au centre du Burkina Faso.” TROPICULTURA 25 (1): 31-6.

[20] Saina, H. 2005. "Guinea Fowl (Numida meleagris) Production under Smallholder Farmer Management in Guruve District, Zimbabwe.” M.Phil. Thesis, Department of Animal Science, Faculty of Agriculture, University of Zimbabwe.

[21] Larbier, M., and Leclerco, B. 1977. Nutrition et alimentation des volailles Tome I. INRA Edition 147, rue de ILL, 175007 Paris.

[22] Ouandaogo, Z. C. 1992. Facteurs freinant le développement de la pintade: problèmes sanitaires. Programme de Développement des Animaux Villageois (PDAV) Ouagadougou, p. 19.

[23] Ouandaogo, Z. C., and Touge, C. 1992. Elevage de la pintade au Burkina-Faso. Programme de Développement des Animaux Villageois (PDAV) Ouagadougou, p. 46.

[24] Somda, J. C. 1987. Etude de la croissance des pintadeaux sur plusieurs types d'alimentation et modes d'élevage. Mém fin d'études, IDR: Ouagadougou.

[25] Kolani, B. 1995. Ethnologie de la pintade: Cas de la Région des Savanes. Mémoire. Ecole Supérieure d'Agronomie. Université de Lomé, 76.

[26] Bessin, R., Belem, A. M. G., Boussini, H., Compaore, Z., Kaboret, Y., and Dembele, M. A. 1998. "Enquête sur les causes de mortalité des pintadeaux au Burkina Faso.” Revue Elev. Méd. vét. Pays Trop. 51: 87-93.

[27] Boussjni, H. 1995. Contribution A l'étude des facteurs de mortalité des pintadeaux au BURKINA FASO. Thèse de médecine vétérinaire. E.I.S.M.V de Dakar.

[28] Laurenson, P. 2002. Détermination des paramètres zootechniques de la pintade locale dans la région du Borgou (mémoire d’Ingénieur). Faculté des Sciences Agronomiques de Gembloux : Gembloux, 2002.

[29] Institut de Selection Animale. 1990. Techniques d'élevage du pintadeau de chair. LYON: ISA, ESSOR., p. 14.

[30] Nagalo, M. 1984. Contribution à l'étude du parasitisme chez la pintade commune (Numida meleagris) en haute-volta, les helminthes parasites du tube digestif. Thèse: Méd. vét.: Dakar, 9.

[31] Bebay, C. 2006. Biosécurité dans les élevages avicoles au Cameroun et au Togo, analyse et perspectives d'amélioration. FAO. www.fao.org/docs/eims/upload//228400/biosecurity_cmr _tgo_fr.pdf.

[32] Diabate, H. 1981. Elevage traditionnel de la pintade en HAUTE-VOLTA. Mémoire de fin d'Etudes, ISP, Ouagadougou.

[33] MAEP. 2012. Programme National d'Investissement Agricole et de Sécurité Alimentaire (PNIASA). Ministère de l’Agriculture de l'élevage et de la pêche. Lomé Togo. 